\title{
Paper and Fiber-Based Bio-Diagnostic Platforms: Current Challenges and Future Needs
}

\author{
Samira Hosseini ${ }^{1,2, *}$, Patricia Vázquez-Villegas ${ }^{1, *}$ and Sergio O. Martínez-Chapa ${ }^{1, *}$ \\ 1 Escuela de Ingeniería y Ciencias, Tecnologico de Monterrey, Ave. Eugenio Garza Sada 2501, \\ Monterrey 64849, NL, Mexico \\ 2 Research Laboratory of Electronics (RLE), Massachusetts Institute of Technology, \\ Cambridge, MA 02139, USA \\ * Correspondence: samira.hosseini@itesm.mx or samira88@mit.edu (S.H.); smart@itesm.mx (S.O.M.-C.); \\ paty.vazquez@itesm.mx (P.V.-V.); Tel.: +52-81-2326-7576 (S.H.); +52-81-8328-4095 (S.O.M-C.)
}

Received: 14 July 2017; Accepted: 18 August 2017; Published: 22 August 2017

\begin{abstract}
In this perspective article, some of the latest paper and fiber-based bio-analytical platforms are summarized, along with their fabrication strategies, the processing behind the product development, and the embedded systems in which paper or fiber materials were integrated. The article also reviews bio-recognition applications of paper/fiber-based devices, the detected analytes of interest, applied detection techniques, the related evaluation parameters, the type and duration of the assays, as well as the advantages and disadvantages of each technique. Moreover, some of the existing challenges of utilizing paper and/or fiber materials are discussed. These include control over the physical characteristics (porosity, permeability, wettability) and the chemical properties (surface functionality) of paper/fiber materials are discussed. Other aspects of the review focus on shelf life, the multi-functionality of the platforms, readout strategies, and other challenges that have to be addressed in order to obtain reliable detection outcomes.
\end{abstract}

Keywords: paper-based bio-analytical devices; shelf life; equipment-free bio-recognition; flow rate; readout strategies; multi-functional platforms

\section{Introduction}

There is an increasing demand in the field of bio-sensing for inexpensive, reliable, portable, rapid, and high throughput analytical devices. The World Health Organization (WHO) defined seven key guidelines for the development of diagnostics platforms suitable for resource-limited areas as major needs for extreme point of care (EPOC): "(i) affordability, (ii) sensitivity, (iii) specificity, (iv) user-friendliness, (v) rapid and robust, (vi) equipment-free, and (vii) deliverable to those in need for such technologies" [1]. These seven requirements recommended by WHO rightfully accumulate to the acronym "ASSURED" [1].

Through diverse applications, in areas such as tissue engineering, controlled drug release, dressings for wound healing, molecular separation, preservation of bioactive compounds, environmental analysis, and food and beverage quality control, etc., paper and fiber-based platforms are now of great importance in healthcare [2-4]. By addressing WHO's guidelines, paper/fiber-based bio-analytical platforms have attracted considerable attention for their effective application in remote/rural and resource-limited areas serving EPOC [5]. Paper and fiber-based materials are generally cost effective, while offering a large, available surface area for biomolecular interaction due to their highly porous structures. Different types of reagent can be stored within their network and benefit from the power-free fluid transport environment occurring through capillary action [2].

Analytical applications of paper in science date to the early 17th century with the use of cellulose papers for chromatographic purposes [6] and $\mathrm{pH}$ sensing [7,8]. A paper-based dipstick 
for quantifying glucose in urine was first introduced to the scientific community in the 1950s, followed by commercialization of the product for a diabetes test one decade later [9]. Historically used for filtration purposes, nitrocellulose membranes were first proposed for molecular recognition in the 1970s [10]. The following decades marked a significant expansion in the application of paper materials for serological lateral flow tests, particularly as pregnancy tests emerged and evolved [11]. Recent advances, particularly in visual bio-diagnostics and hand-held bio-analytical devices, have opened a new and exciting chapter in the development of paper/fiber materials within embedded platforms [12].

Various paper-based bio-sensing platforms were designed and fabricated in recent decades, including dot-immunobinding assays (DIAs), microfluidic paper-based analytical devices ( $\mu$ PADs), lateral flow immunoassay (LFIA), laminated paper-based analytical devices (LPADs), immunospot, nitrocellulose pads (NC-PADs) and paper-based ELISA (P-ELISA) well plates [2-4]. Fabrication of these platforms involves a wide variety of techniques, including plotting [13,14], wax-printing [15-19], inkjet-printing [20,21], flexographic printing [22], computer-controlled knife cutting [23], laser cutting [24,25], vapor-phase polymer deposition [26-28], photolithography [29-34], spraying [35], electrospinning [5,6,36] and coating [37], among others (Table 1) [2,21]. Different aspects of paper-based bio-diagnostic devices, including fabrication strategies, applications for the recognition of various biomolecular entities, the storability as well as the marketability of the paper-based products have been extensively reviewed [2,3,21,38-41].

Considerable potentials of fiber materials in analytical fields offered a vibrant area of research to the scientific community initiated by the introduction of textile materials for chromatographic stationary phases [42]. The high-performance liquid chromatography (HPLC) technique has drawn a great deal of attention toward polymer fibers for separation purposes [43]. High capacity/mass transfer rates, desirable chemistry as well as non-denaturing and re-generable surfaces established fibers as favorable candidates for protein separation with a specific focus on preparative scale separations [43]. In the area of medical diagnostic carbon-based platforms such as single-walled carbon nanotubes (SWCNTs), carbon micro/nano-fibers and composite carbon fibers offered significant advancement in the bio-recognition of a wide range of bio-molecular entities through electrochemical detection [44-46]. Extensive review articles cover significant improvement of carbon-based biosensors in a great detail [46-49]. Polymer-based fibers, in turn, have attracted a great deal of attention in medical diagnostics. Reukov et al., reported nano-coated nylon fibers, which were surface modified to possess positively charged characteristics for bacterial vaginosis detection and pregnancy diseases monitoring [36]. A triple-blend electrospun fiber mat has been used for the clinical diagnostic of colorectal cancer [50]. Wu et al., reported electrospun poly(E-caprolactone) (PCL) fibers for the fluorescent detection of antibody against human serum albumin (anti-HSA) [51]. Polyvinylidene fluoride (PVDF) nano-fiber membrane was used for protein immobilization via Western blotting process [52]. Other examples of fiber platforms are provided in Table 1.

The current perspective article outlines the challenges in controlled physical and chemical properties of the paper/fiber materials, the shelf life, the multi-functionality of the devices, the readout strategies and the ease of operation for the proposed platforms. In that regard, papers and fibers from different categories have been reviewed for their application as bio-receptive platforms for the detection of a broad range of biomolecular entities. Table 2 summarizes some of the latest applications of paper/fiber materials in bio-recognition, particularly for the detection of antibodies, antigens, whole viruses, bacteria, and different classes of proteins via ELISA. Table 2 also presents the type of applied assay, the approximate duration of the assay, and the important evaluation parameters reported for the developed assay. Table 3 outlines some of the major advantages and disadvantages of each technique. Although the presented information in these three tables provides a general insight on how diverse the bio-analytical applications of the paper/fiber materials have been, it also reveals aspects of performance variation amongst the techniques and the shortages and needs that are yet to be addressed. 
Table 1. Paper and fiber-based bio-analytical platforms along with the detailed fabrication methods and embedded systems.

\begin{tabular}{|c|c|c|c|}
\hline Type of Paper/Fiber & Applied Fabrication Method & Embedded Platform/Pattern & Ref. \\
\hline Whatman \# 903 & Dispersion/immersion & Circular fragments sliced with paper punch & [53] \\
\hline \multirow{2}{*}{ Ahlstrom A-55 } & \multirow{2}{*}{ Wax screen printing } & \multirow{2}{*}{$\begin{array}{c}6 \times 3 \text { plate array with hydrophobic barriers as black zones on a } \\
\text { white background }\end{array}$} & [54] \\
\hline & & & [55] \\
\hline Whatmann CHR \# 1 & Photolithography & $\mu \mathrm{PAD}$ with $5 \times 5$ paper mat with a set of electrodes on each side & [56] \\
\hline \multirow{4}{*}{ Whatman \# 1} & \multirow{3}{*}{$\begin{array}{l}\text { Commercialized material with a proprietary } \\
\text { fabrication method }\end{array}$} & $\begin{array}{l}\text { Paper-based disk produced using a standard paper puncher, } \\
\text { dried and taped on a plastic strip }\end{array}$ & [57] \\
\hline & & \multirow{8}{*}{ Designed platform mimics 96 -well plate } & [58] \\
\hline & & & [59] \\
\hline & Wax printing & & {$[60-64$} \\
\hline Whatmann CHR \# 1 & Assembly of paper in pre-cut lamination sheets & & [65] \\
\hline PHB fibers & \multirow{2}{*}{ Electrospinning and dip-coating with poly(MMA-co-MAA) } & & [5] \\
\hline PHBV fibers & & & [6] \\
\hline Nylon & Dip-coating with poly(MMA-co-MAA) & & [37] \\
\hline Cellulose & Photolithography & & [66] \\
\hline Filter paper Whatman \# 42 & \multirow[t]{2}{*}{ Commercialized material with proprietary fabrication method } & $\begin{array}{l}\sim 1 \mathrm{~cm} \text { diameter circles cut into pendent disk shapes to avoid } \\
\text { cross contamination }\end{array}$ & [67] \\
\hline Whatman Fusion $5^{\mathrm{TM}}$ paper & & Square shaped layers with surface area of $3 \mathrm{~cm}^{2}$ & {$[68,69]$} \\
\hline \multirow{2}{*}{ NC } & Wax printing & \multirow{2}{*}{$\mu \mathrm{PAD}$ with printed channels that function as timing valves } & [70] \\
\hline & Inkjet printing & & [71] \\
\hline Whatmann CHR \# 1 & Flexographic printing & $\begin{array}{l}\text { Polystyrene printed paper }(297 \mathrm{~mm} \times 105 \mathrm{~mm}) \text { with } \\
\text { hydrophobic barriers }\end{array}$ & [22] \\
\hline Polyester-backed paper, Whatmann CHR \# 1, NC membrane & Computer-controlled knife cutting & Star, candelabra, and other structures & [23] \\
\hline Aluminum foil-baked Whatmann CHR \# 1 & $\mathrm{CO}_{2}$ laser cutting/engraving & $\mu \mathrm{PAD}$ design with very small features and narrow barriers & [72] \\
\hline Whatman CHR \# 1 coated with functional polymers/copolymers & Vapor-phase polymer deposition & $\begin{array}{l}\text { Integration of multiple advanced unit operations onto a single } \\
\mu \text { PAD device }\end{array}$ & [73] \\
\hline Whatman \# 4 loaded with PEI microcapsules, BCIN, and NBT & Suspension mixing followed by filtration & Paper strips & [74] \\
\hline Nylon \# 6 fibers blended with PSBMA and PAA & \multirow{4}{*}{ Electrospinning } & blended fiber deposition on a glass slip & [50] \\
\hline PVDF nano-fiber membrane & & Western blotting platforms $(6 \mathrm{~cm} \times 8 \mathrm{~cm})$ & [52] \\
\hline Nylon \# 6 fibers with $\mathrm{Cu}-\mathrm{Au}$ nanoparticles & & Paper strips & [75] \\
\hline PCL fiber membrane & & Folded and pressed sheet of membrane $(25 \mathrm{~mm} \times 40 \mathrm{~mm})$ & [51] \\
\hline
\end{tabular}

$\mathrm{NC}=$ nitrocellulose; $\mathrm{PEI}=$ poly(ethyleneimine); $\mathrm{BCIN}=5$-bromo-4-chloro-3-indolyl- $\alpha$-D-N-acetylneuraminic acid; NTB = nitro blue tetrazolium; PVDF = Polyvinylidene fluoride; Cu-Au:

Copper-gold; $\mathrm{PCL}=$ Poly ( $\varepsilon$-caprolactone) . $\mathrm{CHR}=$ chromatography. 
Table 2. Paper and fiber-based bio-analytical platforms directed towards ELISA assays along with the type of target biomolecules, applied detection techniques, and evaluation parameters of the method, as well as the types and approximate durations of the conducted assay.

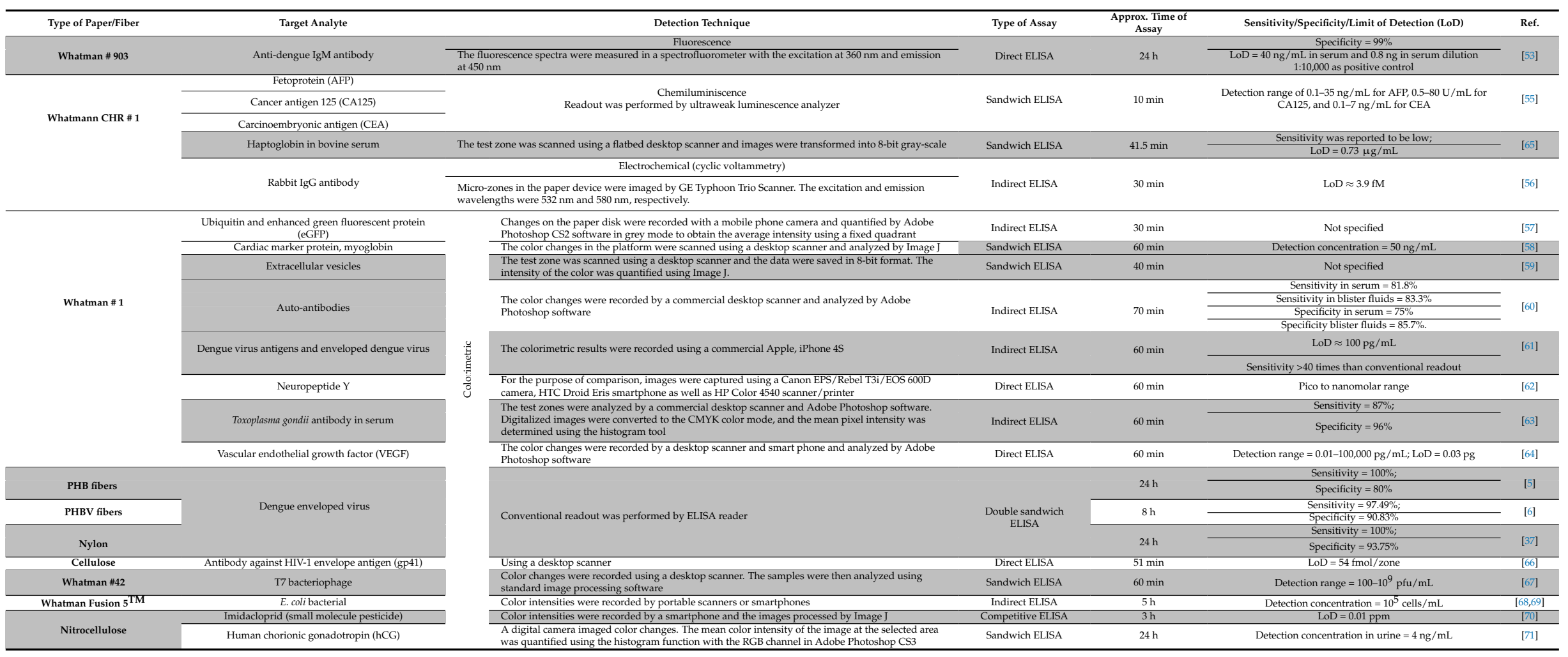


Table 3. Paper and fiber-based bio-analytical platforms along with advantages and disadvantages of applied strategies.

\begin{tabular}{|c|c|c|c|c|}
\hline Paper/Fiber & Strategies & Advantages & Disadvantages & Ref. \\
\hline Whatman \# 903 & $\begin{array}{l}\text { Paper segments were fabricated in the circular } \\
\text { shape by a dispersion/immersion technique for } \\
\text { dengue detection }\end{array}$ & $\begin{array}{l}\text { Improved analytical response, } 2 \text {-fold enhanced } \\
\text { sensitivity with } 700 \text {-fold greater LoD than traditional } \\
\text { ELISA, acceptable accuracy for real sample detection }\end{array}$ & Conducted assay in this study is lengthy & [53] \\
\hline \multirow{3}{*}{ Whatman CHR \# 1} & $\begin{array}{l}\text { Chitosan modified paper microarray with } \\
\text { hydrophobic barriers was fabricated by wax } \\
\text { screen printing for detection of different antigens }\end{array}$ & $\begin{array}{l}\text { Easy translation to other signal reporting } \\
\text { mechanisms, and other biomolecules in point-of-care } \\
\text { devices, with sensitivity and linearity of calibration } \\
\text { curve suitable for clinical application }\end{array}$ & $\begin{array}{l}\text { Neighboring cellulose zones may interfere with } \\
\text { each other; a spaced-detection strategy is } \\
\text { required }\end{array}$ & [55] \\
\hline & $\begin{array}{l}\text { Electrodes integrated } \mu \text { PAD was fabricated by } \\
\text { photolithography for electrochemical detection } \\
\text { of antibody }\end{array}$ & $\begin{array}{l}\text { Higher sensitivity than colorimetric assay, highly } \\
\text { quantitative, fast and efficient, does not require } \\
\text { sophisticated expensive equipment }\end{array}$ & $\begin{array}{l}\text { The method was only used for a model protein } \\
\text { to prove the concept }\end{array}$ & [56] \\
\hline & $\begin{array}{l}\text { Paper assembly in lamination sheets for } \\
\text { haptoglobin detection }\end{array}$ & $\begin{array}{l}\text { Cost-effective compared to the conventional } \\
\text { platform ( } 88 \% \text { reduction in cost) and } 93 \% \text { time } \\
\text { reduction in assay performance }\end{array}$ & $\begin{array}{l}\text { Commercially available ELISA kit can achieve } \\
\text { one order of magnitude lower LoD }\end{array}$ & [65] \\
\hline \multirow{8}{*}{ Whatman \# 1} & Paper-based disk for protein detection & $\begin{array}{l}\text { Non-toxicity of the applied fabrication materials } \\
\text { with wide applications in industry }\end{array}$ & $\begin{array}{l}\text { Almost } 40 \% \text { of antibody molecules desorbed } \\
\text { from cellulose after absorption proving that the } \\
\text { method/material require further optimization }\end{array}$ & [57] \\
\hline & $\begin{array}{l}\text { Mimicked 96-well plate for detection of cardiac } \\
\text { biomarker through colorimetric recognition }\end{array}$ & $\begin{array}{l}\text { The high aspect ratio and high surface coverage of } \\
\text { nanorods provide a large surface area for binding } \\
\text { biomolecules; crystallinity of cellulose supports the } \\
\text { growth of nanorods }\end{array}$ & $\begin{array}{l}\text { Biomolecule penetration into the highly porous } \\
\text { structure of cellulose can cause non-specific } \\
\text { binding and induce errors in the assay }\end{array}$ & [58] \\
\hline & $\begin{array}{l}\text { Mimicked 96-well plate for extracellular vesicles } \\
\text { detection }\end{array}$ & $\begin{array}{l}\text { Compatible with downstream analyses, such as } \\
\text { scanning electron microscopy (SEM), enzyme-linked } \\
\text { immunosorbent assays (ELISA), and transcriptome } \\
\text { analysis }\end{array}$ & $\begin{array}{l}\text { Extracellular vesicles were captured on the } \\
\text { paper device in a non-specific manner; therefore, } \\
\text { the specificity was somewhat compromise }\end{array}$ & [59] \\
\hline & \multirow{5}{*}{$\begin{array}{l}\text { Wax printing technique was applied for } \\
\text { fabrication of paper-based } 96 \text {-well plate aimed } \\
\text { for biorecognition }\end{array}$} & $\begin{array}{l}\text { Rapid and cost-effective analysis in comparison to } \\
\text { conventional ELISA, with similar level of sensitivity } \\
\text { and specificity while utilizing simple equipment and } \\
\text { small sample volumes }\end{array}$ & $\begin{array}{l}\text { Medium range sensitivity and specificity were } \\
\text { reported }\end{array}$ & [60] \\
\hline & & $\begin{array}{l}\text { High sensitivity and specificity, low sample volume, } \\
\text { short operating time }\end{array}$ & Fabrication process is relatively complex & [61] \\
\hline & & $\begin{array}{l}\text { It allows the user to print plates "on-demand" and } \\
\text { opens opportunities for a wide range of nonstandard } \\
\text { formats of customized assays }\end{array}$ & $\begin{array}{l}\text { The method requires specialty software for } \\
\text { image analysis and quantitation }\end{array}$ & [62] \\
\hline & & $\begin{array}{l}\text { Great multiplexing capacity, improved quantitative } \\
\text { outputs, simplified data readout; performed assay at } \\
\text { room temperature that dispenses the need for } \\
\text { refrigeration }\end{array}$ & $\begin{array}{l}\text { Limited to tests with a low number of false } \\
\text { negative outputs }\end{array}$ & [63] \\
\hline & & $\begin{array}{l}\text { Reduced sample volume, higher sensitivity, shorter } \\
\text { assay time, and lower fabrication cost }\end{array}$ & $\begin{array}{l}\text { Low stability and short shelf life, which are } \\
\text { typical drawbacks of the wax printing technique }\end{array}$ & [64] \\
\hline
\end{tabular}


Table 3. Cont

\begin{tabular}{|c|c|c|c|c|}
\hline Paper/Fiber & Strategies & Advantages & Disadvantages & Ref. \\
\hline РHB & \multirow{2}{*}{$\begin{array}{l}\text { Circle shaped polymer coated electrospun fibers } \\
\text { integrated into 96-well plate for dengue } \\
\text { virus detection }\end{array}$} & $\begin{array}{l}\text { Higher sensitivity and specificity than the } \\
\text { conventional method without needing } \\
\text { surface treatments }\end{array}$ & $\begin{array}{l}\text { The need to remove the papers from the well } \\
\text { plate for final readout makes the platform } \\
\text { less efficient }\end{array}$ & [5] \\
\hline PHBV & & $\begin{array}{l}\text { Customized fiber material with tailored surface } \\
\text { properties, tuned wettability and } \\
\text { morphological characteristics }\end{array}$ & $\begin{array}{l}\text { Presence of double-sided adhesive layer might } \\
\text { result in contamination of the samples if } \\
\text { adhesive layer is not fully covered by fiber } \\
\text { mat segments }\end{array}$ & [6] \\
\hline Nylon & $\begin{array}{l}\text { Polymer/copolymer dip-coated nylon } \\
\text { embedded into 96-well plate for dengue } \\
\text { virus detection }\end{array}$ & $\begin{array}{l}\text { Reasonable price, favorable chemistry of the surface } \\
\text { without needing surface treatments }\end{array}$ & $\begin{array}{l}\text { Low stability of the coated nylon membrane in } \\
\text { the assay }\end{array}$ & [37] \\
\hline Cellulose & $\begin{array}{l}\text { Photolithography technique was applied to } \\
\text { fabricate paper-based 96-well plate for detection } \\
\text { of HIV-1 }\end{array}$ & $\begin{array}{l}\text { Offers a rapid analysis that requires small volumes of } \\
\text { samples and reagents, and utilizes simple equipment }\end{array}$ & $\begin{array}{l}\text { The technique is less sensitive than conventional } \\
\text { ELISA by approximately one order of magnitude }\end{array}$ & [66] \\
\hline Whatman \# 42 & $\begin{array}{l}\text { Paper-based disk for detection of T7 } \\
\text { bacteriophage }\end{array}$ & $\begin{array}{l}\text { Compatible with the sophisticated laboratory } \\
\text { diagnostic techniques applied for bio-recognition of } \\
\text { pathogenic viruses and other microorganisms }\end{array}$ & $\begin{array}{l}\text { The sensitivity is comparable to the } \\
\text { sophisticated laboratory diagnostic techniques, } \\
\text { but it is not improved }\end{array}$ & [67] \\
\hline Fusion $5^{\mathrm{TM}}$ & Paper-based ELISA for E. coli detection & $\begin{array}{l}\text { Rapid, low cost ( }<\$ 1 \text { per prototype), short training } \\
\text { time, and minimal medical waste }\end{array}$ & $\begin{array}{l}\text { Detection was only performed for } E \text {. coli sample } \\
\text { within the laboratory, while further clinical } \\
\text { validation is required }\end{array}$ & {$[68,69$} \\
\hline \multirow[t]{2}{*}{ Nitrocellulose } & $\begin{array}{l}\text { Wax printing technique was applied to fabricate } \\
\text { a } \mu \text { PAD equipped with timing valves for } \\
\text { imidacloprid detection }\end{array}$ & $\begin{array}{l}\text { Equipped with timing valve that provides an } \\
\text { opportunity for multiple-step performance in } \\
\text { assay procedure }\end{array}$ & $\begin{array}{l}\text { Similar discrimination capability than } \\
\text { conventional ELISA without any improvement } \\
\text { was reported; the method has to be } \\
\text { further assessed }\end{array}$ & [70] \\
\hline & $\begin{array}{l}\text { Inkjet printing technique was applied to } \\
\text { fabricate a } \mu \text { PAD equipped with timing valves } \\
\text { for hCG detection }\end{array}$ & $\begin{array}{l}\text { Simple, straightforward, and low cost fabrication } \\
\text { technique by using inkjet printing }\end{array}$ & $\begin{array}{l}\text { There is a chance for error and over estimation } \\
\text { of the sensitivity }\end{array}$ & [71] \\
\hline
\end{tabular}


When actual clinical practice is concerned, a small percentage of these techniques open a way for translation from the laboratory bench to the hands of the final users and thus patient care. Even though the currently applied fabrication strategies are promising and the developed prototypes possess tremendous value, further efforts should be dedicated to overcoming the existing limitations. By opening a wide perspective into the bio-sensing domain, the application of papers and fibers has produced an obvious and important shift in the healthcare paradigm. However, several of the developed platforms suffer from a critical lack of reproducibility and limited detection options, as well as insufficient level of sensitivity $[4,76]$. In this perspective article, some of the principal challenges of the developed strategies and the opportunities for future development targets are discussed.

\section{Major Challenges and Opportunities}

\subsection{Physical Characteristics of the Paper and/or Fiber Materials}

The development of a unique surface for improved biomolecular interaction is critical. It requires specifically tailored physical properties of the paper/fiber that can highly encourage analyte-surface interaction through a multitude of forces. In spite of the significant advances in fabrication strategies, paper-based platforms suffer from a lack of control over their physical properties $[4,77]$. Paper segments in most of the developed platforms are selected from commercially available products (Table 1) possessing certain physical characteristics, including capillary flow rate, surface area, porosity, permeability, and wettability. However, these parameters vary significantly from one manufacturer/batch to another, raising the specter of inconsistency $[6,78,79]$.

Capillary flow rate defines the movements of the flow along the length of the paper in the different designs of bio-diagnostic devices. It is the key parameter in assay performance, as the concentration of the target analyte correlates with the speed of the flow rate [78]. While paper is an excellent material for leading and transporting fluids without external forces, control over fluid transfer, the consistency of the flow rate, and the precise direction of the flow are some of the main challenges faced by researchers in this area [2]. Recognizing those challenges, a variety of solutions have been offered to provide a higher degree of control over flow rate. In 2010, Martinez et al. positioned a digital valve that introduced designed gaps to separate the paper's layers, thus strategically connecting and disconnecting the flow [80]. Other groups reported approaches for controlling fluid transport by changing the geometry of the channels and altering the width, length, and thickness of the junctions in paper-based microfluidic designs [81-83]. Applications of the fluidic barriers made from soluble materials for carrier flow were also presented in the literature. These bridges wick fluids until complete dissolution disconnects the flow [82,84,85]. Other techniques, such as phase-switching [86] and razor-crafting channels [87] have also introduced innovative strategies to address this challenge. These techniques have successfully offered higher sensitivity of the assay, enhanced accommodation of small sample volumes within the channels, and the increased retention of the analyte of interest in the network of the paper $[87,88]$.

Although relative hydrophilicity and porosity are desirable features in paper-based devices, as they involve capillary forces for leading fluids in specific directions, those characteristics may also introduce background signal and error into the assay [5,6,37,89]. A high degree of hydrophilicity and porosity are not always favorable for protein immobilization and the subsequent detection of analytes as they may induce biomolecule entrapment, which leads to a false positive signal $[5,6,90]$. Due to the incomplete washing process, and because proteins could be trapped within the highly porous hydrophilic paper matrix, paper-based 96-well plates are normally used to perform double sandwich assays, while evoking a considerable false positive signal $[5,6,37,89,91-94]$. In these assays, a secondary labeled antibody could specifically bind to the primary antibody that is attached to the analyte of interest (Table 2 provides examples of double sandwich assays). If, due to the porosity or swelling condition of the paper or fiber platforms, an excessive level of primary antibodies becomes entangled in the paper matrix, secondary antibodies would most likely bind to the primary antibodies 
without direct attribution to the presence of the analyte, hence producing false signals $[3,5,6,95]$. This phenomenon is, perhaps, the leading cause of non-specific binding inside paper-based devices, which makes them somewhat less reliable and reproducible than other types of bio-analytical platforms with rather impenetrable characteristics. To normalize this effect, negative controls are typically performed in which the analyte of interest is absent thus the biomolecular chain is intentionally broken. The outcomes of the negative readouts are deducted from the actual detection results to obtain reliable detection outcomes. Nonetheless, in evaluating the assay, false positive signals leave an undesirable effect on the specificity and accuracy of the technique [96-100]. High porosity might also be a drawback in lateral flow-based systems due to the lack of control over diffusion of the reagents into the structure of the paper that, in turn, makes the consistency of the flow rate questionable [3]. If the reagents are pushed back into the channels due to the highly porous structure of the paper/fiber materials there is an additional chance for a false positive signal and errors in the assay [3]. The capillary flow rate in leading reagents to the detections zones is of a crucial importance when a reproducible detection outcome with acceptable sensitivity level is the functional target. There is an important need for finely-tuned physical properties of newly developed paper/fiber materials, which could significantly impact their performance and reproducibility in bio-recognition to enhance clinically-relevant results.

\subsection{Chemical Characteristics of the Paper/Fiber Materials and the Need for Surface Modification}

A variety of paper types have been used, or integrated into, a wide range of analytical designs to produce bio-sensing platforms (Tables 1 and 2). Porous cellulose is perhaps the most widely used commercial material in a majority of these designs (Table 1). Although the chemical structure of cellulose offers an abundance of hydroxyl $(-\mathrm{OH})$ functional groups, these moieties are not highly reactive towards biomolecular entities. Consequently, in most cases, surface modification is required to modulate the functional nature of the paper materials [2,4]. Strategic alterations of the surface could also result in the enhanced control of fluidic flow, improved color uniformity (in the case of colorimetric detection), enhanced chemical stability of the surface, the fabrication of microfluidic valves (in the case of $\mu \mathrm{PADs}$ ), as well as the generation of chemically reactive functionalities [2]. The presence of chemically reactive space through functionalization by carboxyl $(-\mathrm{COOH})$ and / or amine $\left(-\mathrm{NH}_{2}\right)$ groups, highly encourages the development of analyte-surface interactions through both physical and covalent immobilization. If active functional groups, such as $-\mathrm{COOH}$ and / or $-\mathrm{NH}_{2}$, are optimally generated on the surface, there is a high chance for involving biomolecules in ionic attractions and hydrophobic interactions, as well as for hydrogen bonding opportunities $[5,94]$. These forces and reactions are known to play prominent roles in protein immobilization, which would result in the subsequent attachment of the complementary biomolecules, thereby producing an improved final biological response generated from the bio-receptive surfaces.

Apart from the intricacy of the modification strategies, the natural characteristics of the paper materials are frequently compromised during the treatment procedures [2]. Aggressive treatments might also contaminate papers due to exposure to the different chemicals and reagents (Table 3) [2]. In addition, papers are reported to lose their original shape subsequent to chemical treatment, having a tendency to curl or wrinkle after modifications are made. This may make their application difficult for specific types of bio-diagnostic platforms [3]. Furthermore, even if the properties of the paper are not affected by modification techniques, there might be no ability to carefully control the generation of active functional groups and their focused distribution on the paper surface [101,102]. Optimal generation and distribution of the surface functional groups are crucial in biomolecule immobilization and subsequent detection of the analyte of interest. Overly functionalized surfaces tend to reject/hinder approaching biomolecules due to the steric repulsion, while an insufficient concentration of active functionalities may cause the biomolecules to fall on the surface and lose activity $[91,102,103]$. Therefore, a suitable bio-receptive platform would be credited for its substantial surface area and controlled wettability and porosity, and for an effective chemical design that can 
offer a protein-friendly surface with high occurrence and reproducibility for bimolecular interaction associated with binding stability.

In that perspective, the development of customized paper/fiber materials with improved control over physical and chemical material properties would appear to be a highly desirable solution. Different characterization techniques are typically used to analyze the physical and the chemical properties of the newly developed materials. Water-in-air contact angle analysis can determine the wettability of the paper/fiber samples $[5,6,104,105]$. The morphology of the papers/fibers can be recorded by scanning electron micorscopy (SEM) and the fiber diameter range can be subsequently measured by analyzing SEM micrographs by using different software such as Image $J[5,6,37,106]$. Porosity and permeability of the paper/fiber networks can be analyzed by bulk density method, gas permeability techniques or X-ray computed tomography (X-CT) [106-109]. Other techniques such as Raman spectroscopy, Fourier transform infrared spectroscopy (FTIR), and X-ray photoelectron spectroscopy (XPS) can provide detailed information regarding the chemistry of the surface. These analytical techniques are well established in the laboratory and industrial setups. Nonetheless, close control over material properties and reproducibility of the products can be achieved through fabrication strategies. The consistency of the physical and chemical characteristics of the developed paper/fiber materials eliminates the risk of errors in the analytical assays and provides with accurate detection outcomes.

One alternative approach to overcome such limitations could be the use of and electrospinning technique (particularly three-dimensional (3D) electrospinning setup) in which the diameter range of the fiber and the porosity could be closely controlled, and different classes of bulk materials could be selected for fabrication of the fibers. If the chosen material or one of the combined materials has desirable active functional groups in its chemical structure, then the fabrication process can be finely adjusted in order to obtain and optimal concentration of the necessary functional groups without the need for surface modification strategies $[5,6]$. Unlike the chemical modification techniques, this alternative approach would not harm the original nature of the paper material, and the stability of the surface functionalities is guaranteed, as they are an integral aspect of the chemical fingerprint of the constructed matrix, and would not lose their activity over time.

\subsection{Shelf Life of the Paper/Fiber Materials}

Apart from the efficiency of the developed platforms, the reproducible shelf life of the products is also of a great importance. With the significant advances in the fabrication of paper-based devices, the resulting paper products remain sensitive materials, with low tensile strength, and high vulnerability to modulations in environmental conditions, particularly temperature and humidity $[3,54,55]$. Table 4 summarizes the shelf life details of some of the conventional, commercial, and novel paper/fiber materials. Researchers face challenges maintaining the shelf life of the commonly used paper materials (e.g., porous cellulose and nitrocellulose) even prior to the application of surface modification techniques [54,55]. Porous cellulose products such as Ahlstrom A-55 and Whatman CHR (chromatography) \# 1 can provide reproducible results for at least five weeks if it is stored at $4{ }^{\circ} \mathrm{C}$ under sealed conditions (Table 4) $[54,55]$. The shelf life of nitrocellulose and nylon materials is reported to be approximately 3 and 7 months, respectively $[110,111]$. Fiber substitutes, such as polyhydroxybutyrate (PHB) and poly(3-hydroxybutyrate-co-3-hydroxyvalerate) (PHBV), however, are reported to be more stable towards temperature change and possess relatively high degradation temperatures (Table 4) [112-116]. 
Table 4. Shelf life and stability of the paper and fiber materials applied for bio-analytical applications.

\begin{tabular}{|c|c|c|c|}
\hline Type of Paper/1 & & Shelf Life/Stability & Ref. \\
\hline \multirow{3}{*}{ Conventional and commercial materials } & Whatman CHR \# 1 & $\begin{array}{l}\text { Lab-on-paper immuno-devices, constructed with this material can provide reproducible } \\
\text { results upon storage at } 4{ }^{\circ} \mathrm{C} \text { (sealed) for at least } 5 \text { weeks [54]. In other studies on } \\
\text { antibody immobilization on the surface of this material, the stability decreased with } \\
\text { increasing temperature and relative humidity }\left(40^{\circ} \mathrm{C} \text {, half-life was more than } 10 \text { days) }\right. \\
\text { and was dependent on relative humidity (RH) [55]. However, at } 80^{\circ} \mathrm{C} \text {, the half-life } \\
\text { varied from } \sim 3 \text { days at low } \mathrm{RH} \text { to less than half an hour at } 90 \% \mathrm{RH} \text { ) [55]. }\end{array}$ & [55] \\
\hline & Nitrocellulose & $\begin{array}{l}\text { The material is commonly used in lateral flow assays. For the detection of } P \text {. brasiliensis } \\
\text { B- } 339 \text { antigen, } 91 \% \text { sensitivity and } 95.4 \% \text { specificity was reported, while the membrane } \\
\text { have proved to be viable for use in at least } 90 \text { days after sensitization. }\end{array}$ & [110] \\
\hline & Nylon & $\begin{array}{l}\text { The stability of nylon membranes is relatively high [37]. Impregnated protein in the } \\
\text { network of nylon has the shelf life of several months (at least } 7 \text { months) with minimal } \\
\text { loss in activity; the immobilized enzymes within nylon's structure remain active for at } \\
\text { least } 33 \text { h without significant loss of activity [111]. }\end{array}$ & {$[37,111]$} \\
\hline \multirow[b]{2}{*}{ Commercial materials } & Whatman \# 903 & $\begin{array}{l}\text { Thermal degradation of the material occurs above } 300^{\circ} \mathrm{C} \text { [53]. Antibodies dried on filter } \\
\text { papers are not affected by the duration of storage if kept frozen for over } 1 \text { year at } \\
-20^{\circ} \mathrm{C} \text { [117]. Although reactivity of the antibodies decreases after storage, it was not } \\
\text { found to interfere with the specificity of the assay even after } 13 \text { years if stored as dry } \\
\text { spots on filter paper [117]. }\end{array}$ & {$[53,117]$} \\
\hline & Fusion $5^{\mathrm{TM}}$ & $\begin{array}{l}\text { This glass-fiber based material offers the benefits of a high rate of absorption, } \\
\text { an acceptable wicking area, optimal wicking time, and homogeneous color } \\
\text { development [68]. As a substrate for DNA biosensor strips, stored at } 37^{\circ} \mathrm{C} \text {, } \\
\text { it maintained its activity up to } 30 \text { days; this translates to an estimated shelf life of } \\
103.87 \text { days at ambient temperature }\left(24{ }^{\circ} \mathrm{C}\right) \text { [69]. Fusion } 5 \text { contains a plastic binder to } \\
\text { increase its mechanical strength [118]. }\end{array}$ & {$[68,69,118]$} \\
\hline \multirow[t]{2}{*}{ Non-commercial materials } & PHB & $\begin{array}{l}\text { PHB is highly crystalline (approximately } 80 \% \text { ) with a melting temperature close to } \\
180^{\circ} \mathrm{C} \text { [116]. PHB provides a great resistance to water, which indicates that relative } \\
\text { humidity will not affect its performance }[5,113] \text {. Relatively stiff PHB is biodegradable, } \\
\text { low cost, biocompatible and non-toxic, which are desirable features for a platform in } \\
\text { bio-applications [115]. }\end{array}$ & {$[5,113,115,116]$} \\
\hline & PHBV & 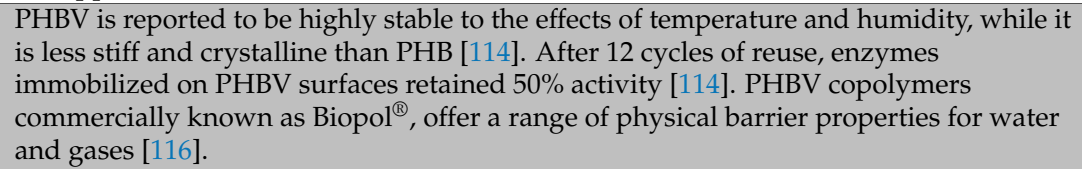 & {$[114,116]$} \\
\hline
\end{tabular}


Apart from the bio-receptive material itself, the duration in which the impregnated proteins in the structure of the papers/fibers remain active is vital. Higher stability of the biomolecules and a longer shelf life for the developed materials permits the long-distance transportation of the platforms to where they are mostly needed, under-privileged areas. Immobilized antibodies in the network of porous cellulose (Whatman CHR \# 1 and Ahlstrom A-55) were found to lose their activity with increasing temperature $\left(\sim 40^{\circ} \mathrm{C}\right)$ while the stability of the impregnated product over time was significantly affected with an increase in relative humidity (RH) (Table 4) [54,55]. Other studies have established that antibodies can remain active for a long period under optimal storage conditions $\left(-20{ }^{\circ} \mathrm{C}\right)$ if impregnated using a dry-reagent technique $[67,119]$.

Papers are often harshly affected by the treatment processes, which may make them even more sensitive than in their original states. As mentioned, papers are reported to lose their shape on treatment, tending to curl, fold, or wrinkle after modifications, which makes their application difficult in the specific design of bio-diagnostic platforms [3]. When conducting immunoassays, untreated papers seldom undergo numerous steps of washing and incubation, which makes them very difficult to preserve. If, prior to use in immunoassays, the papers are also subjected to additional harsh treatments, it is even less likely for them to remain intact throughout the assay. Therefore, fabrication strategies should be designed to minimize surface modification steps while generating active functional groups and providing a higher chance for preservation of the platforms. An alternative strategy could be customization of the bio-receptive paper/fiber platforms (as presented in Table 1, PHB and PHBV), which would permit choices of reference materials with tailored properties that can naturally offer desirable features and improved stability over time [5,6].

\subsection{Readout Outcomes}

One of the critical steps in working with paper-/fiber-based devices is the ability to quantify the analytes of interest with minimal requirements. The major challenge, particularly when EPOC in remote/rural areas is the aim, is to achieve reasonably accurate bio-diagnosis without needing centralized clinical facilities and sophisticated, expensive equipment. In the context of on-site diagnosis, reliable quantitative or semi-quantitative readouts are anticipated to dictate the treatment by a simple "yes/no" or "normal/abnormal" responses [2,120]. In this path, significant progress has been made.

A variety of techniques, including colorimetry [120-123], fluorescent [29,123-127], luminescent [128], chemiluminiscent [128,129], photo-electro-chemiluminiscent, electrochemical [130,131], electro-chemiluminiscent [132,133], and photo-electrochemical [134] detections have been reported for paper and/or fiber-based bio-diagnostic platforms $[2-4,135,136]$. In the case of fluorescence readout, an important question is: "To what extent does the whiteness of the paper play a role in producing a background signal or perhaps participating in the bleaching effect?". The most commonly-used analytical detection technique for paper/fiber-based devices is colorimetric (Table 2) [2,3]. This analysis is known to be relatively straightforward; the color intensity is proportional to the concentration of the analyte; the operating time is relatively short, and the detectors are normally portable and inexpensive, while the technique is mainly compatible with smart devices [2].

The likelihood of telemedicine using digital cameras, cell phones, and smart devices was demonstrated since 2008 for glucose detection in artificial urine $[137,138]$. Detection via smart devices has rapidly penetrated the worldwide market introducing tremendous opportunities for the on-site processing of data, instead of sample transfer to a centralized clinical facility (Table 2) [2,57-71,128,139]. With their storage capacity, smart devices serve clinical practice well, enabling information to be collected and stored to a much greater extent than previously possible. Modern smart devices possess both a light source (LED flash) and a digital camera for detection; therefore they are capable of performing tasks that are normally performed by expensive techniques, such as fluorometers, spectrophotometers, or silicon photodetectors [140].

Novel attempts have also been dedicated to non-instrumented analysis or equipment-free detection techniques for fabricating easy-to-use paper-based devices that can play vital roles in 
EPOC [121]. Such strategies would reduce the cost of bio-diagnosis, while increasing the portability of the devices that do not require external readout instrumentation [141,142]. One approach to perform equipment-free analysis relies upon color intensity comparators using an external calibration or standard calibration integrated within the device $[143,144]$. Weaver et al. reported a cost-effective "color barcode" test for the rapid screening and quality control of pharmaceutical drugs [145]. The fabricated device was divided into twelve individual lanes, on which the solid pharmaceutical product was mounted and the edge dipped into the chosen media. Each lane specifically reacted to one type of analyte (e.g., ampicillin, amoxicillin, and rifampicin) and a corresponding colored lane, visually compared with the reference was indicative of a "positive I.D." [145]. Another interesting study by Zhu et al. reported a self-calibrating sensor for glucose measurement. The tree-shaped, branched structure of the designed platform minimized the ambient effects, such as temperature and humidity [146]. Pollock et al. reported self-calibration of the device based on alteration of the incubation time [147]. This study suggests that the sensitivity of the device was in an acceptable range $(84 \%)$, even though the readout outcome was semi-quantitative [147]. Such studies establish that visual assessment of the detection outcomes can be adequately robust if a reliable control over the ambient conditions is implemented.

Other interesting non-instrumented approaches are known as distance-based detections $[148,149]$. Zuk et al. reported the measurement of biological samples by calculating a total distance a colorimetric reagent has traveled across the paper channel. In this method, the distance wicked by the product is proportional to the analyte concentration [148]. A similar strategy that gained considerable popularity due to its simplicity and applicability was presented by Lou et al. [150]. This distance-based detection strategy introduced breaking points in the continuous flow path. Each discrete segment that turned colored participated in the final calculation of the analyte concentration [150].

Another alternative, equipment-free, detection approach is known as time-based analysis. In this strategy, the time required for signal development is the performance merit. Lewis et al. developed a system for enzyme quantification with a control zone to account for the ambient conditions (e.g., temperature, humidity, pressure, and sample viscosity) [151]. Combined with a self-calibrating system, this time-based detection strategy changes the incubation time to minimize the influence of external parameters and to elicit a reliable readout signal. Further advances in the time-based measurement involved a phase-switching design of the platform in which specific types of oligomers depolymerize themselves in the presence of target analyte [86]. Oligomers are hydrophobic in their nature; however, they tend to become hydrophilic after depolymerization, thereby allowing the flow to travel through the channel and reach the detection zone. Once the analyte of interest arrives at the final destination, the color change occurs; an indication of assay completion. The rate and the time of depolymerization were found to be proportional to the concentration of the target analyte. In these types of assay, all that is required is a timer, which makes the technique highly favorable for EPOC application in remote/rural areas.

\subsection{Multi-Functionality of the Platforms}

One of the major missions of the paper-based devices, especially in the area of microfluidics, is to increase the functionality of the devices. The ability to achieve multi-step processing and performance makes $\mu$ PADs highly favorable for EPOC applications [23,39,41]. Lutz et al. and Fu et al. studied the sequential delivery of multiple reagents by creating flow paths of varying lengths in order to automate a sandwich ELISA assay $[119,152]$. Li et al. demonstrated devices capable of performing a multi-step assay by incorporating a magnetically-timed valve [153]. By placing it down or raising it above the channel, the valve would close or open the path for the fluids in a controlled manner. This method, however, had its own limitations, as the valve is for a single use only and it consumes large quantities of the reagents, since a unique timing sequence has to be designed for every new assay.

One of the beneficial strategies to increase multi-functionality of the paper-/fiber-based devices is the dry-reagent approach. If all the necessary reagents are added to the device in the dry state it 
will provide (i) a reduced number of steps to be taken by the final user; (ii) easier shipment of the kits, since reagents are loaded within the network of the paper; and (iii) higher stability of the product when dealing with environmental changes, such as temperature and humidity [154]. Reported examples of $\mu$ PADs combined with a dry-reagent strategy have proven to be more amenable to the multi-step processing employed in the assay [154].

\subsection{Easy Operation for Onsite Health Check}

Even though the majority of paper/fiber-based platforms are aimed at hand-held diagnosis, sample collection and preparation for such devices may introduce considerable challenges. The necessity for sample processing steps, such as separation (e.g., whole blood, serum, and plasma), mixing, adding reagents, and washing among others, falls short of the principles of user-friendliness [38]. In the case of whole blood, specific components/proteins must be removed from the sample to increase the sensitivity and specificity of detection [155]. Normally, plasma should be separated from the whole blood prior to the measurements to minimize errors related to light scattering, absorption, hemolysis, or coagulation of the red blood cells [40]. In the ideal case of a test system, no sample preparation, system calibration, data interpretation, or calculation for end users should be expected [38]. In reality, however, even in well-equipped laboratories, sample preparation suffers from various shortfalls, such as inhomogeneity and the variable viscosity of the samples, as well as presence of interfering agents [3]. The most error-prone aspect of diagnostic tests in laboratories is known to be the pre-analytical phase (sample processing) that includes blood tube sorting, centrifugation, cap removal, sample aliquoting, and recapping [40]. A number of techniques have been developed to offer analysis by individuals with minimal training outside centralized laboratories, such as in doctor's offices, emergency rooms, ambulances, etc. In the context of onsite POC/EPOC and for the technologies to be broadly accepted by the end users in remote/rural areas or elderly people, clear results have to be obtained without the need of any additional processing or external instrument.

High throughput systems incorporated into the paper-based devices have automated the separation step by using a diverse range of solid materials, including beads, microparticles, fiber matrices, and coated tubes and plates [147,156-163]. Additionally, application of pre-depositing agglutination antibodies, concentrated salt solution for blood cell deformation and filtering via paper pores using capillary force are known to be effective techniques for sample separation [164-166]. In the case of paper strips, the platforms generally contain segments that are designed for automated mixing of the specimen with dry reagents $[40,158]$. In such devices, a manual step is normally required to finalize the sample separation. More sophisticated platforms, which enable automation of several sample preparation steps without manual intervention have also been reported. While offering beneficial features, such as automated multistep assays, generally the result is an enlargement of the device dimensions and additional material costs $[38,167,168]$. Readers are recommended to study the excellent reviews by Yamada et al., 2017 and Cunningham, 2001 for detailed information [38,40]. In nucleic acid analysis, sample preparation comprises labor-intensive multiple steps, including suspension, mixing, centrifugation, washing, and elution of the nucleic acids, that are generally performed in dedicated laboratories to minimize cross-contamination and the generation of false positive results $[40,169]$.

According to the Clinical Laboratory Improvement Amendments (CLIA) guidelines (formulated by the U.S. Food \& Drug Administration (FDA), any user with a 7th-grade English level should be able to readily operate the diagnostic devices aimed for application outside laboratories after following the instructions provided by the manufacturer $[38,170]$. Despite advances in sample preparation and fluidics handling, there is obviously considerable room for improvements in the commercialization of more user-friendly devices. 


\subsection{Other Considerations}

Have the great potential of paper/fiber materials been fully acknowledged by diagnosis manufacturers? Can paper/fiber materials overcome the existing limitations of bio-diagnostic platforms? Would it be possible for an entire bio-analytical assay to be built upon a single type of paper/fiber material? If so, can paper/fiber meet the necessary performance requirements of an efficient bio-analytical platform, such as sensitivity, specificity, cost-effectiveness, and rapid analysis, etc.? To exploit the full potential of paper/fiber materials for bio-analytical applications, these questions need to be addressed. Several other essential points are also worthy of consideration; the following section outlines some of these aspects:

(1) In paper/fiber diagnostic platforms (especially dipsticks), certain segments of the platforms are impregnated with different biomolecular entities, such as antibodies, that specifically bind to the analyte of interest [3]. In this regard, the question might be raised about the yield for such specific binding when dealing with impregnated paper/fiber networks. What is the variation in the uptake or conjugation of the analytes? How consistent is the occurrence of conjugation and the release from conjugation? How fast or slow do these binding and release processes occur? Are these rates reproducible for such assays?

(2) Another aspect of paper/fiber platforms that requires attention is the possibility of contamination of the platforms during the fabrication or treatment processes (Table 3). Cross-contamination from the run-over (spillage) between adjacent reagents remains a separate issue [171-173]. Several efforts have been made to curtail these contamination effects, including the development of hydrophobic barriers designed within the structure of the paper-based devices that partially addresses the spillage of the reagents [171-174]. However, there is also a risk of toxicity for the biological samples when they are in close contact with the fabrication materials, such as waxes, paraffins, or toxic chemicals used in the techniques for functional modification [3]. How can the risk of contamination be fully eliminated from the fabrication, treatment, and operation procedures of paper-/fiber-based devices? Can the incompatibility of the surfactants with proteins be carefully evaluated?

(3) Some of the latest advances in the development of paper-/fiber-based devices offer complex platforms that are hard to be reproduced on an industrial scale. Intricacies can also occur in the protocols, which are then beyond the expertise of the laboratory technicians who perform the tests as their everyday routine (Table 3). Multilayered platforms that are composed of several different segments that need to be carefully assembled prior to test application, layers that are often attached with adhesive components that most likely denature/deactivate analytes when placed in close proximity of the biomolecules, seem less likely to become the next generation of conventional, reproducible, bio-analytical devices used in day-to-day clinical practice. In that perspective, the development of novel platforms with less complexity in fabrication and application should provide a higher probability for prototype development and commercialization.

\section{General Conclusions}

Paper and fiber materials are some of the main components in many analytical devices used in the healthcare domain. They offer a number of advantages, including cost-effectiveness, rapid diagnostic, as well as desirable characteristics, such as relative hydrophilicity, porosity, permeability, and high surface area. When bio-sensing is the target function, additional steps of improvement are necessary when applying paper/fiber materials. Firstly, the physical and chemical properties of the materials, such as surface wettability, porosity, and the presence of active surface functional groups must be closely controlled. Shelf life and stability of the developed platforms should also be considered and monitored, since paper materials incorporated in bio-analytical platforms often undergo lengthy incubations and numerous pipetting processes. Surface modification strategies may 
impose unintentional changes on the nature of the paper, as well as modulating its chemical/physical properties. In conclusion, suitable paper- and/or fiber-based bio-sensing platforms should be created for high throughput detection performance and specificity, and be associated with great stability of the functional material, as well as the selected and impregnated biomolecules in the paper matrix, while the platforms should be easy to manipulate technically, have the capacity to provide unambiguous and reproducible results, and be amenable to mass production.

Acknowledgments: The authors would like to acknowledge the financial support of Tecnologico de Monterrey, for the grant (002EICII01) awarded to the Sensors and Devices Focus Group, School of Engineering and Sciences, Tecnologico de Monterrey, Monterrey, Mexico. Samira Hosseini would like to thank Professor David Danielson Eaton for his support and the helpful discussion. The authors deeply appreciate the assistance of Professor Emeritus Geoffrey A. Cordell for the English editing of this manuscript.

Author Contributions: Samira Hosseini designed the outlines and wrote the paper. Patricia Vázquez-Villegas designed the Tables and contributed in drafting the paper. Sergio O. Martínez-Chapa guided the authors and provided with the scientific insights. All the authors have contributed in the final draft of the manuscript.

Conflicts of Interest: The authors declare no conflict of interest.

\section{References}

1. Urdea, M.; Penny, L.A.; Olmsted, S.S.; Giovanni, M.Y.; Kaspar, P.; Shepherd, A. Requirements for high impact diagnostics in the developing world. Nature 2006, 444, 73-79. [CrossRef] [PubMed]

2. Cate, D.M.; Adkins, J.A.; Mettakoonpitak, J.; Henry, C.S. Recent developments in paper-based microfluidic devices. Anal. Chem. 2014, 87, 19-41. [CrossRef] [PubMed]

3. Yetisen, A.K.; Akram, M.S.; Lowe, C.R. Paper-based microfluidic point-of-care diagnostic devices. Lab Chip 2013, 13, 2210-2251. [CrossRef] [PubMed]

4. Ahmed, S.; Bui, M.-P.N.; Abbas, A. Paper-based chemical and biological sensors: Engineering aspects. Biosens. Bioelectron. 2016, 77, 249-263. [CrossRef] [PubMed]

5. Hosseini, S.; Azari, P.; Farahmand, E.; Gan, S.N.; Rothan, H.A.; Yusof, R. Polymethacrylate coated electrospun PHB fibers: An exquisite outlook for fabrication of paper-based biosensors. Biosens. Bioelectron. 2015, 69, 257-264. [CrossRef] [PubMed]

6. Hosseini, S.; Azari, P.; Aeinehvand, M.M.; Rothan, H.A.; Djordjevic, I.; Martinez-Chapa, S.O. Intrant ELISA: A Novel Approach to Fabrication of Electrospun Fiber Mat-Assisted Biosensor Platforms and Their Integration within Standard Analytical Well Plates. Appl. Sci. 2016, 6, 336. [CrossRef]

7. Gribnau, T.; Leuvering, J.; Van Hell, H. Particle-labelled immunoassays: A review. J. Chromatogr. B Biomed. Sci. Appl. 1986, 376, 175-189. [CrossRef]

8. Wilson, R. The use of gold nanoparticles in diagnostics and detection. Chem. Soc. Rev. 2008, 37, 2028-2045. [CrossRef] [PubMed]

9. Free, A.H.; Adams, E.C.; Kercher, M.L.; Free, H.M.; Cook, M.H. Simple specific test for urine glucose. Clin. Chem. 1957, 3, 163-168. [PubMed]

10. Towbin, H.; Staehelin, T.; Gordon, J. Electrophoretic transfer of proteins from polyacrylamide gels to nitrocellulose sheets: Procedure and some applications. Proc. Natl. Acad. Sci. USA 1979, 76, 4350-4354. [CrossRef] [PubMed]

11. A Timeline of Pregnancy Testing. Available online: https://history.nih.gov/exhibits/thinblueline/timeline. html (accessed on 15 May 2017).

12. Sher, M.; Zhuang, R.; Demirci, U.; Asghar, W. Paper-based analytical devices for clinical diagnosis: Recent advances in the fabrication techniques and sensing mechanisms. Expert Rev. Mol. Diagn. 2017, 17, 351-366. [CrossRef] [PubMed]

13. Bruzewicz, D.A.; Reches, M.; Whitesides, G.M. Low-cost printing of poly (dimethylsiloxane) barriers to define microchannels in paper. Anal. Chem. 2008, 80, 3387-3392. [CrossRef] [PubMed]

14. Nie, J.; Zhang, Y.; Lin, L.; Zhou, C.; Li, S.; Zhang, L. Low-cost fabrication of paper-based microfluidic devices by one-step plotting. Anal. Chem. 2012, 84, 6331-6335. [CrossRef] [PubMed]

15. Lu, Y.; Shi, W.; Jiang, L.; Qin, J.; Lin, B. Rapid prototyping of paper-based microfluidics with wax for low-cost, portable bioassay. Electrophoresis 2009, 30, 1497-1500. [CrossRef] [PubMed] 
16. Carrilho, E.; Martinez, A.W.; Whitesides, G.M. Understanding wax printing: A simple micropatterning process for paper-based microfluidics. Anal. Chem. 2009, 81, 7091-7095. [CrossRef] [PubMed]

17. Schilling, K.M.; Lepore, A.L.; Kurian, J.A.; Martinez, A.W. Fully enclosed microfluidic paper-based analytical devices. Anal. Chem. 2012, 84, 1579-1585. [CrossRef] [PubMed]

18. Songjaroen, T.; Dungchai, W.; Chailapakul, O.; Laiwattanapaisal, W. Novel, simple and low-cost alternative method for fabrication of paper-based microfluidics by wax dipping. Talanta 2011, 85, 2587-2593. [CrossRef] [PubMed]

19. Zhang, A.-L.; Zha, Y. Fabrication of paper-based microfluidic device using printed circuit technology. Aip Adv. 2012, 2, 022171. [CrossRef]

20. Abe, K.; Suzuki, K.; Citterio, D. Inkjet-printed microfluidic multianalyte chemical sensing paper. Anal. Chem. 2008, 80, 6928-6934. [CrossRef] [PubMed]

21. He, Y.; Wu, Y.; Fu, J.-Z.; Wu, W.-B. Fabrication of paper-based microfluidic analysis devices: A review. RSC Adv. 2015, 5, 78109-78127. [CrossRef]

22. Olkkonen, J.; Lehtinen, K.; Erho, T. Flexographically printed fluidic structures in paper. Anal. Chem. 2010, 82, 10246-10250. [CrossRef] [PubMed]

23. Fenton, E.M.; Mascarenas, M.R.; López, G.P.; Sibbett, S.S. Multiplex lateral-flow test strips fabricated by two-dimensional shaping. ACS Appl. Mater. Interfaces 2008, 1, 124-129. [CrossRef] [PubMed]

24. Nie, J.; Liang, Y.; Zhang, Y.; Le, S.; Li, D.; Zhang, S. One-step patterning of hollow microstructures in paper by laser cutting to create microfluidic analytical devices. Analyst 2013, 138, 671-676. [CrossRef] [PubMed]

25. Spicar-Mihalic, P.; Toley, B.; Houghtaling, J.; Liang, T.; Yager, P.; Fu, E. $\mathrm{CO}_{2}$ laser cutting and ablative etching for the fabrication of paper-based devices. J. Micromech. Microeng. 2013, 23, 067003. [CrossRef]

26. Haller, P.D.; Flowers, C.A.; Gupta, M. Three-dimensional patterning of porous materials using vapor phase polymerization. Soft Matter 2011, 7, 2428-2432. [CrossRef]

27. Demirel, G.; Babur, E. Vapor-phase deposition of polymers as a simple and versatile technique to generate paper-based microfluidic platforms for bioassay applications. Analyst 2014, 139, 2326-2331. [CrossRef] [PubMed]

28. Chen, B.; Kwong, P.; Gupta, M. Patterned fluoropolymer barriers for containment of organic solvents within paper-based microfluidic devices. ACS Appl. Mater. Interfaces 2013, 5, 12701-12707. [CrossRef] [PubMed]

29. Carrilho, E.; Phillips, S.T.; Vella, S.J.; Martinez, A.W.; Whitesides, G.M. Paper microzone plates. Anal. Chem. 2009, 81, 5990-5998. [CrossRef] [PubMed]

30. He, Q.; Ma, C.; Hu, X.; Chen, H. Method for fabrication of paper-based microfluidic devices by alkylsilane self-assembling and UV/O3-patterning. Anal. Chem. 2013, 85, 1327-1331. [CrossRef] [PubMed]

31. He, Y.; Wu, W.-B.; Fu, J.-Z. Rapid fabrication of paper-based microfluidic analytical devices with desktop stereolithography 3D printer. RSC Adv. 2015, 5, 2694-2701. [CrossRef]

32. OuYang, L.; Wang, C.; Du, F.; Zheng, T.; Liang, H. Electrochromatographic separations of multi-component metal complexes on a microfluidic paper-based device with a simplified photolithography. RSC Adv. 2014, 4, 1093-1101. [CrossRef]

33. Songok, J.; Tuominen, M.; Teisala, H.; Haapanen, J.; Mäkelä, J.; Kuusipalo, J. Paper-based microfluidics: Fabrication technique and dynamics of capillary-driven surface flow. ACS Appl. Mater. Interfaces 2014, 6, 20060-20066. [CrossRef] [PubMed]

34. Sones, C.; Katis, I.; He, P.; Mills, B.; Namiq, M.; Shardlow, P. Laser-induced photo-polymerisation for creation of paper-based fluidic devices. Lab Chip 2014, 14, 4567-4574. [CrossRef] [PubMed]

35. Dungchai, W.; Chailapakul, O.; Henry, C.S. A low-cost, simple, and rapid fabrication method for paper-based microfluidics using wax screen-printing. Analyst 2011, 136, 77-82. [CrossRef] [PubMed]

36. Reukov, V.; Vertegel, A.; Burtovyy, O.; Kornev, K.; Luzinov, I.; Miller, P. Fabrication of nanocoated fibers for self-diagnosis of bacterial vaginosis. Mater. Sci. Eng. C 2009, 29, 669-673. [CrossRef]

37. Farahmand, E.; Ibrahim, F.; Hosseini, S.; Rothan, H.A.; Yusof, R.; Koole, L.H. A novel approach for application of nylon membranes in the biosensing domain. Appl. Surf. Sci. 2015, 353, 1310-1319. [CrossRef]

38. Yamada, K.; Shibata, H.; Suzuki, K.; Citterio, D. Toward practical application of paper-based microfluidics for medical diagnostics: State-of-the-art and challenges. Lab Chip 2017, 17, 1206-1249. [CrossRef] [PubMed]

39. Gong, M.M.; Sinton, D. Turning the Page: Advancing Paper-Based Microfluidics for Broad Diagnostic Application. Chem. Rev. 2017, 117, 8447-8480. [CrossRef] [PubMed] 
40. Cunningham, D.D. Fluidics and sample handling in clinical chemical analysis. Anal. Chim. Acta 2001, 429, 1-18. [CrossRef]

41. Xia, Y.; Si, J.; Li, Z. Fabrication techniques for microfluidic paper-based analytical devices and their applications for biological testing: A review. Biosens. Bioelectron. 2016, 77, 774-789. [CrossRef] [PubMed]

42. Friedman, H.; Miller, B.; Meiser, C., Jr. Influence of preadsorbed water on chromatographic detention of organic volatiles by cellulosic substrates. Text. Res. J. 1985, 55, 726-732. [CrossRef]

43. Marcus, R.K. Use of polymer fiber stationary phases for liquid chromatography separations: Part II-Applications. J. Sep. Sci. 2009, 32, 695-705. [CrossRef] [PubMed]

44. Grigoryev, A.; Sa, V.; Gopishetty, V.; Tokarev, I.; Kornev, K.G.; Minko, S. Wet-Spun Stimuli-Responsive Composite Fibers with Tunable Electrical Conductivity. Adv. Funct. Mater. 2013, 23, 5903-5909. [CrossRef]

45. Le Goff, A.; Holzinger, M.; Cosnier, S. Enzymatic biosensors based on SWCNT-conducting polymer electrodes. Analyst 2011, 136, 1279-1287. [CrossRef] [PubMed]

46. Wohlstadter, J.N.; Wilbur, J.L.; Sigal, G.B.; Biebuyck, H.A.; Billadeau, M.A.; Dong, L. Carbon nanotube-based biosensor. Adv. Mater. 2003, 15, 1184-1187. [CrossRef]

47. Georgakilas, V.; Otyepka, M.; Bourlinos, A.B.; Chandra, V.; Kim, N.; Kemp, K.C. Functionalization of graphene: Covalent and non-covalent approaches, derivatives and applications. Chem. Rev. 2012, 112, 6156-6214. [CrossRef] [PubMed]

48. Baptista, F.R.; Belhout, S.; Giordani, S.; Quinn, S. Recent developments in carbon nanomaterial sensors. Chem. Soc. Rev. 2015, 44, 4433-4453. [CrossRef] [PubMed]

49. Zheng, X.T.; Ananthanarayanan, A.; Luo, K.Q.; Chen, P. Glowing graphene quantum dots and carbon dots: Properties, syntheses, and biological applications. Small 2015, 11, 1620-1636. [CrossRef] [PubMed]

50. Tseng, H.-C.; Lee, A.-W.; Wei, P.-L.; Chang, Y.-J.; Chen, J.-K. Clinical diagnosis of colorectal cancer using electrospun triple-blend fibrous mat-based capture assay of circulating tumor cells. J. Mater. Chem. B 2016, 4, 6565-6580. [CrossRef]

51. Steckl, A.; Wu, D.; Han, D. Immunoassay on Free-standing Electrospun Membranes. In Proceedings of the APS March Meeting, Portland, OR, USA, 15-19 March 2010. Abstracts 2010.

52. Cho, E.; Kim, C.; Kook, J.-K.; Jeong, Y.I.; Kim, J.H.; Kim, Y.A. Fabrication of electrospun PVDF nanofiber membrane for Western blot with high sensitivity. J. Membr. Sci. 2012, 389, 349-354. [CrossRef]

53. Ortega, G.; Pérez-Rodríguez, S.; Reguera, E. Magnetic paper-based ELISA for IgM-dengue detection. RSC Adv. 2017, 7, 4921-4932. [CrossRef]

54. Wang, J.; Yiu, B.; Obermeyer, J.; Filipe, C.D.; Brennan, J.D.; Pelton, R. Effects of temperature and relative humidity on the stability of paper-immobilized antibodies. Biomacromolecules 2012, 13, 559-564. [CrossRef] [PubMed]

55. Wang, S.; Ge, L.; Song, X.; Yu, J.; Ge, S.; Huang, J. Paper-based chemiluminescence ELISA: Lab-on-paper based on chitosan modified paper device and wax-screen-printing. Biosens. Bioelectron. 2012, 31, 212-218. [CrossRef] [PubMed]

56. Li, X.; Nie, Z.; Cheng, C.; Goodale, A.; Whitesides, G. Paper-based electrochemical ELISA. In Proceedings of the 14th International Conference on Miniaturized Systems for Chemistry and Life Sciences (MicroTAS 2010), Groningen, The Netherlands, 3-7 October 2010; pp. 1487-1489.

57. Chan, S.K.; Lim, T.S. A straw-housed paper-based colorimetric antibody-antigen sensor. Anal. Methods 2016, 8, 1431-1436. [CrossRef]

58. Tiwari, S.; Vinchurkar, M.; Rao, V.R.; Garnier, G. Zinc oxide nanorods functionalized paper for protein preconcentration in biodiagnostics. Sci. Rep. 2017, 7, 43905. [CrossRef] [PubMed]

59. Chen, C.; Lin, B.-R.; Wang, H.-K.; Fan, S.-T.; Hsu, M.-Y.; Cheng, C.-M. Paper-based immunoaffinity devices for accessible isolation and characterization of extracellular vesicles. Microfluid. Nanofluid. 2014, 16, 849-856. [CrossRef]

60. Hsu, C.-K.; Huang, H.-Y.; Chen, W.-R.; Nishie, W.; Ujiie, H.; Natsuga, K. Paper-Based ELISA for the Detection of Autoimmune Antibodies in Body Fluid-The Case of Bullous Pemphigoid. Anal. Chem. 2014, 86, 4605-4610. [CrossRef] [PubMed]

61. Wang, H.K.; Tsai, C.H.; Chen, K.H.; Tang, C.T.; Leou, J.S.; Li, P.C. Cellulose-Based Diagnostic Devices for Diagnosing Serotype-2 Dengue Fever in Human Serum. Adv. Healthc. Mater. 2014, 3, 187-196. [CrossRef] [PubMed] 
62. Murdock, R.C.; Shen, L.; Griffin, D.K.; Kelley-Loughnane, N.; Papautsky, I.; Hagen, J.A. Optimization of a paper-based ELISA for a human performance biomarker. Anal. Chem. 2013, 85, 11634-11642. [CrossRef] [PubMed]

63. Mazzu-Nascimento, T.; Morbioli, G.G.; Milan, L.A.; Silva, D.F.; Donofrio, F.C.; Mestriner, C.A. Improved assessment of accuracy and performance indicators in paper-based ELISA. Anal. Methods 2017, 9, $2644-2653$. [CrossRef]

64. Hsu, M.-Y.; Hung, Y.-C.; Hwang, D.-K.; Lin, S.-C.; Lin, K.-H.; Wang, C.-Y. Detection of aqueous VEGF concentrations before and after intravitreal injection of anti-VEGF antibody using low-volume sampling paper-based ELISA. Sci. Rep. 2016, 6, 34631. [CrossRef] [PubMed]

65. Busin, V.; Burgess, S.; Shu, W. A Novel Multi-pad Paper Plate (MP 3) Based Assays for Rapid Animal Disease Diagnostics. Procedia Eng. 2016, 168, 1418-1421. [CrossRef]

66. Cheng, C.M.; Martinez, A.W.; Gong, J.; Mace, C.R.; Phillips, S.T.; Carrilho, E. Paper-based ELISA. Angew. Chem. Int. Ed. 2010, 49, 4771-4774. [CrossRef] [PubMed]

67. Khan, M.S.; Pande, T.; van de Ven, T.G. Qualitative and quantitative detection of T7 bacteriophages using paper based sandwich ELISA. Colloids Surf. B Biointerfaces 2015, 132, 264-270. [CrossRef] [PubMed]

68. Shih, C.-M.; Chang, C.-L.; Hsu, M.-Y.; Lin, J.-Y.; Kuan, C.-M.; Wang, H.-K. Paper-based ELISA to rapidly detect Escherichia coli. Talanta 2015, 145, 2-5. [CrossRef] [PubMed]

69. Jones, K. FUSION 5: A New Platform For Lateral Flow Immunoassay Tests. In Lateral Flow Immunoassay; Springer: New York, NY, USA, 2009; pp. 1-15.

70. Lai, Y.-T.; Tsai, J.-S.; Hsu, J.-C.; Lu, Y.-W. Automated paper-based devices by microfluidic timing-valve for competitive ELISA. In Proceedings of the 2017 IEEE 30th International Conference on Micro Electro Mechanical Systems (MEMS), Las Vegas, NV, USA, 22-26 January 2017; pp. 1321-1324.

71. Apilux, A.; Ukita, Y.; Chikae, M.; Chailapakul, O.; Takamura, Y. Development of automated paper-based devices for sequential multistep sandwich enzyme-linked immunosorbent assays using inkjet printing. Lab Chip 2013, 13, 126-135. [CrossRef] [PubMed]

72. Mahmud, M.A.; Blondeel, E.J.M.; Kaddoura, M.; MacDonald, B.D. Creating compact and microscale features in paper-based devices by laser cutting. Analyst 2016, 141, 6449-6454. [CrossRef] [PubMed]

73. Kwong, P.; Gupta, M. Vapor Phase Deposition of Functional Polymers onto Paper-Based Microfluidic Devices for Advanced Unit Operations. Anal. Chem. 2012, 84, 10129-10135. [CrossRef] [PubMed]

74. Zhang, Y.; Rochefort, D. Fast and effective paper based sensor for self-diagnosis of bacterial vaginosis. Anal. Chim. Acta 2013, 800, 87-94. [CrossRef] [PubMed]

75. Mudabuka, B.; Ondigo, D.; Degni, S.; Vilakazi, S.; Torto, N. A colorimetric probe for ascorbic acid based on copper-gold nanoparticles in electrospun nylon. Microchim. Acta 2014, 181, 395-401. [CrossRef]

76. Ge, L.; Wang, P.; Ge, S.; Li, N.; Yu, J.; Yan, M. Photoelectrochemical Lab-on-Paper Device Based on an Integrated Paper Supercapacitor and Internal Light Source. Anal. Chem. 2013, 85, 3961-3970. [CrossRef] [PubMed]

77. Yeow, N.; McLiesh, H.; Guan, L.; Shen, W.; Garnier, G. Paper-based assay for red blood cell antigen typing by the indirect antiglobulin test. Anal. Bioanal. Chem. 2016, 408, 5231-5238. [CrossRef] [PubMed]

78. Chong, H.; Koo, Y.; Collins, B.; Gomez, F.; Yun, Y.; Sankar, J. Paper-based microfluidic point-of-care diagnostic devices for monitoring drug metabolism. J. Nanomed. Biother. Discov. 2013, 3, e122. [CrossRef]

79. Li, X.; Tian, J.; Shen, W. Progress in patterned paper sizing for fabrication of paper-based microfluidic sensors. Cellulose 2010, 17, 649-659. [CrossRef]

80. Martinez, A.W.; Phillips, S.T.; Nie, Z.; Cheng, C.-M.; Carrilho, E.; Wiley, B.J. Programmable diagnostic devices made from paper and tape. Lab Chip 2010, 10, 2499-2504. [CrossRef] [PubMed]

81. Toley, B.J.; McKenzie, B.; Liang, T.; Buser, J.R.; Yager, P.; Fu, E. Tunable-delay shunts for paper microfluidic devices. Anal. Chem. 2013, 85, 11545-11552. [CrossRef] [PubMed]

82. Fu, E.; Lutz, B.; Kauffman, P.; Yager, P. Controlled reagent transport in disposable 2D paper networks. Lab Chip 2010, 10, 918-920. [CrossRef] [PubMed]

83. Tian, J.; Kannangara, D.; Li, X.; Shen, W. Capillary driven low-cost V-groove microfluidic device with high sample transport efficiency. Lab Chip 2010, 10, 2258-2264. [CrossRef] [PubMed]

84. Lutz, B.; Liang, T.; Fu, E.; Ramachandran, S.; Kauffman, P.; Yager, P. Dissolvable fluidic time delays for programming multi-step assays in instrument-free paper diagnostics. Lab Chip 2013, 13, $2840-2847$. [CrossRef] [PubMed] 
85. Houghtaling, J.; Liang, T.; Thiessen, G.; Fu, E. Dissolvable bridges for manipulating fluid volumes in paper networks. Anal. Chem. 2013, 85, 11201-11204. [CrossRef] [PubMed]

86. Lewis, G.G.; Robbins, J.S.; Phillips, S.T. Phase-switching depolymerizable poly(carbamate) oligomers for signal amplification in quantitative time-based assays. Macromolecules 2013, 46, 5177-5183. [CrossRef]

87. Giokas, D.L.; Tsogas, G.Z.; Vlessidis, A.G. Programming fluid transport in paper-based microfluidic devices using razor-crafted open channels. Anal. Chem. 2014, 86, 6202-6207. [CrossRef] [PubMed]

88. Renault, C.; Anderson, M.J.; Crooks, R.M. Electrochemistry in hollow-channel paper analytical devices. J. Am. Chem. Soc. 2014, 136, 4616-4623. [CrossRef] [PubMed]

89. Hosseini, S.; Ibrahim, F.; Djordjevic, I.; Rothan, H.A.; Yusof, R.; van der Mareld, C. Synthesis and Processing of ELISA Polymer Substitute: The Influence of Surface Chemistry and Morphology on Detection Sensitivity. Appl. Surf. Sci. 2014, 317, 630-638. [CrossRef]

90. Li, L.; Ma, C.; Kong, Q.; Li, W.; Zhang, Y.; Ge, S. A 3D origami electrochemical immunodevice based on a Au@ Pd alloy nanoparticle-paper electrode for the detection of carcinoembryonic antigen. J. Mater. Chem. B 2014, 2, 6669-6674. [CrossRef]

91. Hosseini, S.; Ibrahim, F.; Rothan, H.A.; Yusof, R.; van der Marel, C.; Djordjevic, I. Aging effect and antibody immobilization on -COOH exposed surfaces designed for dengue virus detection. Biochem. Eng. J. 2015, 99, 183-192. [CrossRef]

92. Hosseini, S.; Ibrahim, F.; Djordjevic, I.; Rothan, H.A.; Yusof, R.; van der Marel, C. Synthesis and characterization of methacrylic microspheres for biomolecular recognition: Ultrasensitive biosensor for dengue virus detection. Eur. Polym. J. 2014, 60, 14-21. [CrossRef]

93. Hosseini, S.; Ibrahim, F. Application of Biochips in Dengue Virus Detection. In Novel Polymeric Biochips for Enhanced Detection of Infectious Diseases; Springer: Singapore, 2016; pp. 39-47.

94. Hosseini, S.; Aeinehvand, M.M.; Uddin, S.M.; Benzina, A.; Rothan, H.A.; Yusof, R. Microsphere integrated microfluidic disk: Synergy of two techniques for rapid and ultrasensitive dengue detection. Sci. Rep. 2015, 5, 16485. [CrossRef] [PubMed]

95. Zhong, Z.; Wang, Z.; Huang, G.X. Investigation of wax and paper materials for the fabrication of paper-based microfluidic devices. Microsyst. Technol. 2012, 18, 649-659. [CrossRef]

96. Shrivastava, A.; Gupta, V.B. Methods for the determination of limit of detection and limit of quantitation of the analytical methods. Chron. Young Sci. 2011, 2, 21-25. [CrossRef]

97. Swamy, N.; Prashanth, K.N.; Basavaiah, K. Titrimetric and spectrophotometric assay of diethylcarbamazine citrate in formulations using iodate and iodide mixture as reagents. Braz. J. Pharm. Sci. 2015, 51, 43-52. [CrossRef]

98. Gad, M.; Zaazaa, H.; Amer, S.; Korany, M. Static headspace gas chromatographic method for the determination of residual solvents in cephalosporins. RSC Adv. 2015, 5, 17150-17159. [CrossRef]

99. Bauer, S.M.; Gehringer, M.; Laufer, S.A. A direct enzyme-linked immunosorbent assay (ELISA) for the quantitative evaluation of Janus Kinase 3 (JAK3) inhibitors. Anal. Methods 2014, 6, 8817-8822. [CrossRef]

100. Pereira, A.G.; D'Avila, F.B.; Ferreira, P.C.L.; Holler, M.G.; Limberger, R.P.; Froehlich, P.E. Determination of cocaine, its metabolites and pyrolytic products by LC-MS using a chemometric approach. Anal. Methods 2014, 6, 456-462. [CrossRef]

101. Hosseini, S.; Ibrahim, F.; Djordjevic, I.; Koole, L.H. Recent advances in surface functionalization techniques on polymethacrylate materials for optical biosensor applications. Analyst 2014, 139, 2933-2943. [CrossRef] [PubMed]

102. Goddard, J.M.; Hotchkiss, J.H. Polymer surface modification for the attachment of bioactive compounds. Prog. Polym. Sci. 2007, 32, 698-725. [CrossRef]

103. Hosseini, S.; Ibrahim, F. Current Optical Biosensors in Clinical Practice. In Novel Polymeric Biochips for Enhanced Detection of Infectious Diseases; Springer: Singapore, 2016; pp. 1-12.

104. Tsai, C.-C.; Gu, Y.; Kornev, K.G. Wetting of nanofiber yarns. Colloids Surf. Physicochem. Eng. Asp. 2014, 459, 22-30. [CrossRef]

105. Saraf, R.; Lee, H.J.; Michielsen, S.; Owens, J.; Willis, C.; Stone, C. Comparison of three methods for generating superhydrophobic, superoleophobic nylon nonwoven surfaces. J. Mater. Sci. 2011, 46, 5751-5760. [CrossRef]

106. Guo, A.; Roso, M.; Modesti, M.; Maire, E.; Adrien, J.; Colombo, P. Characterization of porosity, structure, and mechanical properties of electrospun SiOC fiber mats. J. Mater. Sci. 2015, 50, 4221-4231. [CrossRef] 
107. Dinger, D.R. Characterization Techniques for Ceramists; Dinger Ceramic Consulting Services: Clemson, SC, USA, 2005.

108. Etiemble, A.; Adrien, J.; Maire, E.; Idrissi, H.; Reyter, D.; Roué, L. 3D morphological analysis of copper foams as current collectors for Li-ion batteries by means of X-ray tomography. Mater. Sci. Eng. B 2014, 187, 1-8. [CrossRef]

109. Biasetto, L.; Colombo, P.; Innocentini, M.D.; Mullens, S. Gas permeability of microcellular ceramic foams. Ind. Eng. Chem. Res. 2007, 46, 3366-3372. [CrossRef]

110. Kamikawa, C.M.; Mendes, R.P.; Vicentini, A.P. Standardization and validation of Dot-ELISA assay for Paracoccidioides brasiliensis antibody detection. J. Venom. Anim. Toxins Trop. Dis. 2017, 23, 11. [CrossRef] [PubMed]

111. Xu, F.; Wang, W.-H.; Tan, Y.-J.; Bruening, M.L. Facile trypsin immobilization in polymeric membranes for rapid, efficient protein digestion. Anal. Chem. 2010, 82, 10045-10051. [CrossRef] [PubMed]

112. Hosseini, S.; Ibrahim, F.; Djordjevic, I.; Koole, L.H. Polymethyl methacrylate-co-methacrylic acid coatings with controllable concentration of surface carboxyl groups: A novel approach in fabrication of polymeric platforms for potential bio-diagnostic devices. Appl. Surf. Sci. 2014, 300, 43-50. [CrossRef]

113. Mahalik, N.P.; Nambiar, A.N. Trends in food packaging and manufacturing systems and technology. Trends Food Sci. Technol. 2010, 21, 117-128. [CrossRef]

114. Cabrera-Padilla, R.Y.; Lisboa, M.C.; Fricks, A.T.; Franceschi, E.; Lima, A.S.; Silva, D.P. Immobilization of Candida rugosa lipase on poly (3-hydroxybutyrate-co-hydroxyvalerate): A new eco-friendly support. J. Ind. Microbiol. Biotechnol. 2012, 39, 289-298. [CrossRef] [PubMed]

115. Ma, X.; Liu, X.; Xiao, H.; Li, G. Direct electrochemistry and electrocatalysis of hemoglobin in poly-3-hydroxybutyrate membrane. Biosens. Bioelectron. 2005, 20, 1836-1842. [CrossRef] [PubMed]

116. Cheng, M.-L.; Sun, Y.-M.; Chen, H.; Jean, Y. Change of structure and free volume properties of semi-crystalline poly (3-hydroxybutyrate-co-3-hydroxyvalerate) during thermal treatments by positron annihilation lifetime. Polymer 2009, 50, 1957-1964. [CrossRef]

117. Ferraz, A.S.; Belo, E.F.; Coutinho, L.M.; Oliveira, A.P.; Carmo, A.M.; Franco, D.L. Storage and stability of IgG and IgM monoclonal antibodies dried on filter paper and utility in Neisseria meningitidis serotyping by Dot-blot ELISA. BMC Infect. Dis. 2008, 8, 30. [CrossRef] [PubMed]

118. Nargang, T.M.; Runck, M.; Helmer, D.; Rapp, B.E. Functionalization of paper using photobleaching: A fast and convenient method for creating paper-based assays with colorimetric and fluorescent readout. Eng. Life Sci. 2016, 16, 525-531. [CrossRef]

119. Lutz, B.R.; Trinh, P.; Ball, C.; Fu, E.; Yager, P. Two-dimensional paper networks: Programmable fluidic disconnects for multi-step processes in shaped paper. Lab Chip 2011, 11, 4274-4278. [CrossRef] [PubMed]

120. Lopez-Ruiz, N.; Curto, V.F.; Erenas, M.M.; Benito-Lopez, F.; Diamond, D.; Palma, A.J. Smartphone-based simultaneous $\mathrm{pH}$ and nitrite colorimetric determination for paper microfluidic devices. Anal. Chem. 2014, 86, 9554-9562. [CrossRef] [PubMed]

121. Wang, H.; Li, Y.-J.; Wei, J.-F.; Xu, J.-R.; Wang, Y.-H.; Zheng, G.-X. Paper-based three-dimensional microfluidic device for monitoring of heavy metals with a camera cell phone. Anal. Bioanal. Chem. 2014, 406, 2799-2807. [CrossRef] [PubMed]

122. Zhang, Y.; Zhou, C.; Nie, J.; Le, S.; Qin, Q.; Liu, F. Equipment-free quantitative measurement for microfluidic paper-based analytical devices fabricated using the principles of movable-type printing. Anal. Chem. 2014, 86, 2005-2012. [CrossRef] [PubMed]

123. Zhang, M.; Ge, L.; Ge, S.; Yan, M.; Yu, J.; Huang, J. Three-dimensional paper-based electrochemiluminescence device for simultaneous detection of $\mathrm{Pb} \mathrm{2}+$ and $\mathrm{Hg} 2+$ based on potential-control technique. Biosens. Bioelectron. 2013, 41, 544-550. [CrossRef] [PubMed]

124. Ali, M.M.; Aguirre, S.D.; Xu, Y.; Filipe, C.D.; Pelton, R.; Li, Y. Detection of DNA using bioactive paper strips. Chem. Commun. 2009, 43, 6640-6642. [CrossRef] [PubMed]

125. Allen, P.B.; Arshad, S.A.; Li, B.; Chen, X.; Ellington, A.D. DNA circuits as amplifiers for the detection of nucleic acids on a paperfluidic platform. Lab Chip 2012, 12, 2951-2958. [CrossRef] [PubMed]

126. Yildiz, U.H.; Alagappan, P.; Liedberg, B. Naked eye detection of lung cancer associated miRNA by paper based biosensing platform. Anal. Chem. 2012, 85, 820-824. [CrossRef] [PubMed] 
127. Noor, M.O.; Shahmuradyan, A.; Krull, U.J. Paper-based solid-phase nucleic acid hybridization assay using immobilized quantum dots as donors in fluorescence resonance energy transfer. Anal. Chem. 2013, 85, 1860-1867. [CrossRef] [PubMed]

128. Delaney, J.L.; Hogan, C.F.; Tian, J.; Shen, W. Electrogenerated chemiluminescence detection in paper-based microfluidic sensors. Anal. Chem. 2011, 83, 1300-1306. [CrossRef] [PubMed]

129. Yu, J.; Wang, S.; Ge, L.; Ge, S. A novel chemiluminescence paper microfluidic biosensor based on enzymatic reaction for uric acid determination. Biosens. Bioelectron. 2011, 26, 3284-3289. [CrossRef] [PubMed]

130. Rattanarat, P.; Dungchai, W.; Cate, D.; Volckens, J.; Chailapakul, O.; Henry, C.S. Multilayer paper-based device for colorimetric and electrochemical quantification of metals. Anal. Chem. 2014, 86, 3555-3562. [CrossRef] [PubMed]

131. Scida, K.; Cunningham, J.C.; Renault, C.; Richards, I.; Crooks, R.M. Simple, sensitive, and quantitative electrochemical detection method for paper analytical devices. Anal. Chem. 2014, 86, 6501-6507. [CrossRef] [PubMed]

132. Wu, L.; Ma, C.; Ge, L.; Kong, Q.; Yan, M.; Ge, S. Paper-based electrochemiluminescence origami cyto-device for multiple cancer cells detection using porous AuPd alloy as catalytically promoted nanolabels. Biosens. Bioelectron. 2015, 63, 450-457. [CrossRef] [PubMed]

133. Li, W.; Li, M.; Ge, S.; Yan, M.; Huang, J.; Yu, J. Battery-triggered ultrasensitive electrochemiluminescence detection on microfluidic paper-based immunodevice based on dual-signal amplification strategy. Anal. Chim. Acta 2013, 767, 66-74. [CrossRef] [PubMed]

134. Sun, G.; Wang, P.; Ge, S.; Ge, L.; Yu, J.; Yan, M. Photoelectrochemical sensor for pentachlorophenol on microfluidic paper-based analytical device based on the molecular imprinting technique. Biosens. Bioelectron. 2014, 56, 97-103. [CrossRef] [PubMed]

135. Maxwell, E.J.; Mazzeo, A.D.; Whitesides, G.M. Paper-based electroanalytical devices for accessible diagnostic testing. MRS Bull. 2013, 38, 309-314. [CrossRef]

136. Liu, B.; Du, D.; Hua, X.; Yu, X.Y.; Lin, Y. Paper-Based Electrochemical Biosensors: From Test Strips to Paper-Based Microfluidics. Electroanalysis 2014, 26, 1214-1223. [CrossRef]

137. Martinez, A.W.; Phillips, S.T.; Carrilho, E.; Thomas, S.W., III; Sindi, H.; Whitesides, G.M. Simple telemedicine for developing regions: Camera phones and paper-based microfluidic devices for real-time, off-site diagnosis. Anal. Chem. 2008, 80, 3699-3707. [CrossRef] [PubMed]

138. Martinez, A.W.; Phillips, S.T.; Whitesides, G.M.; Carrilho, E. Diagnostics for the developing world: Microfluidic paper-based analytical devices. Anal. Chem. 2010, 82, 3-10. [CrossRef] [PubMed]

139. Aungst, T.D.; Clauson, K.A.; Misra, S.; Lewis, T.L.; Husain, I. How to identify, assess and utilise mobile medical applications in clinical practice. Int. J. Clin. Pract. 2014, 68, 155-162. [CrossRef] [PubMed]

140. Doeven, E.H.; Barbante, G.J.; Kerr, E.; Hogan, C.F.; Endler, J.A.; Francis, P.S. Red-green-blue electrogenerated chemiluminescence utilizing a digital camera as detector. Anal. Chem. 2014, 86, 2727-2732. [CrossRef] [PubMed]

141. Fu, E. Enabling robust quantitative readout in an equipment-free model of device development. Analyst 2014, 139, 4750-4757. [CrossRef] [PubMed]

142. Phillips, S.T.; Lewis, G.G. Advances in materials that enable quantitative point-of-care assays. MRS Bull. 2013, 38, 315-319. [CrossRef]

143. Fang, X.; Wei, S.; Kong, J. Paper-based microfluidics with high resolution, cut on a glass fiber membrane for bioassays. Lab Chip 2014, 14, 911-915. [CrossRef] [PubMed]

144. Hao, Y.; Chen, W.; Wang, L.; Zhou, B.; Zang, Q.; Chen, S. A naphthalimide-based azo colorimetric and ratiometric probe: Synthesis and its application in rapid detection of cyanide anions. Anal. Methods 2014, 6, 2478-2483. [CrossRef]

145. Weaver, A.A.; Reiser, H.; Barstis, T.; Benvenuti, M.; Ghosh, D.; Hunckler, M. Paper analytical devices for fast field screening of beta lactam antibiotics and antituberculosis pharmaceuticals. Anal. Chem. 2013, 85, 6453-6460. [CrossRef] [PubMed]

146. Zhu, W.-J.; Feng, D.-Q.; Chen, M.; Chen, Z.-D.; Zhu, R.; Fang, H.-L. Bienzyme colorimetric detection of glucose with self-calibration based on tree-shaped paper strip. Sens. Actuators B Chem. 2014, 190, 414-418. [CrossRef]

147. Pollock, N.R.; McGray, S.; Colby, D.J.; Noubary, F.; Nguyen, H.; Khormaee, S. Field evaluation of a prototype paper-based point-of-care fingerstick transaminase test. PLoS ONE 2013, 8, e75616. [CrossRef] [PubMed] 
148. Zuk, R.; Ginsberg, V.; Houts, T.; Rabbie, J.; Merrick, H.; Ullman, E. Enzyme immunochromatography-A quantitative immunoassay requiring no instrumentation. Clin. Chem. 1985, 31, 1144-1150. [PubMed]

149. Cate, D.M.; Dungchai, W.; Cunningham, J.C.; Volckens, J.; Henry, C.S. Simple, distance-based measurement for paper analytical devices. Lab Chip 2013, 13, 2397-2404. [CrossRef] [PubMed]

150. Lou, S.C.; Patel, C.; Ching, S.; Gordon, J. One-step competitive immunochromatographic assay for semiquantitative determination of lipoprotein (a) in plasma. Clin. Chem. 1993, 39, 619-624. [PubMed]

151. Lewis, G.G.; DiTucci, M.J.; Phillips, S.T. Quantifying Analytes in Paper-Based Microfluidic Devices Without Using External Electronic Readers. Angew. Chem. 2012, 124, 12879-12882. [CrossRef]

152. Fu, E.; Ramsey, S.A.; Kauffman, P.; Lutz, B.; Yager, P. Transport in two-dimensional paper networks. Microfluid. Nanofluid. 2011, 10, 29-35. [CrossRef] [PubMed]

153. Li, X.; Zwanenburg, P.; Liu, X. Magnetic timing valves for fluid control in paper-based microfluidics. Lab Chip 2013, 13, 2609-2614. [CrossRef] [PubMed]

154. Fridley, G.E.; Le, H.; Yager, P. Highly sensitive immunoassay based on controlled rehydration of patterned reagents in a 2-dimensional paper network. Anal. Chem. 2014, 86, 6447-6453. [CrossRef] [PubMed]

155. Whatman, G.H. Catalog CDwb; Whatman, Inc.: Maidstone, UK, 2007.

156. Fiore, M.; Mitchell, J.; Doan, T.; Nelson, R.; Winter, G.; Grandone, C. The Abbott IMx automated benchtop immunochemistry analyzer system. Clin. Chem. 1988, 34, 1726-1732. [PubMed]

157. Smith, J.; Osikowicz, G. Abbott AxSYM random and continuous access immunoassay system for improved workflow in the clinical laboratory. Clin. Chem. 1993, 39, 2063-2069. [PubMed]

158. Sokoll, L.J.; Chan, D.W. Clinical analyzers. immunoassays. Anal. Chem. 1999, 71, 356-362. [CrossRef]

159. Vella, S.J.; Beattie, P.; Cademartiri, R.; Laromaine, A.; Martinez, A.W.; Phillips, S.T. Measuring markers of liver function using a micropatterned paper device designed for blood from a fingerstick. Anal. Chem. 2012, 84, 2883-2891. [CrossRef] [PubMed]

160. Noiphung, J.; Songjaroen, T.; Dungchai, W.; Henry, C.S.; Chailapakul, O.; Laiwattanapaisal, W. Electrochemical detection of glucose from whole blood using paper-based microfluidic devices. Anal. Chim. Acta 2013, 788, 39-45. [CrossRef] [PubMed]

161. Songjaroen, T.; Dungchai, W.; Chailapakul, O.; Henry, C.S.; Laiwattanapaisal, W. Blood separation on microfluidic paper-based analytical devices. Lab Chip 2012, 12, 3392-3398. [CrossRef] [PubMed]

162. Pollock, N.R.; Rolland, J.P.; Kumar, S.; Beattie, P.D.; Jain, S.; Noubary, F. A paper-based multiplexed transaminase test for low-cost, point-of-care liver function testing. Sci. Transl. Med. 2012, 4, 152 ra129. [CrossRef] [PubMed]

163. Jain, S.; Rajasingham, R.; Noubary, F.; Coonahan, E.; Schoeplein, R.; Baden, R. Performance of an Optimized Paper-Based Test for Rapid Visual Measurement of Alanine Aminotransferase (ALT) in Fingerstick and Venipuncture Samples. PLoS ONE 2015, 10, e0128118. [CrossRef] [PubMed]

164. Yang, X.; Forouzan, O.; Brown, T.P.; Shevkoplyas, S.S. Integrated separation of blood plasma from whole blood for microfluidic paper-based analytical devices. Lab Chip 2012, 12, 274-280. [CrossRef] [PubMed]

165. Nilghaz, A.; Shen, W. Low-cost blood plasma separation method using salt functionalized paper. RSC Adv. 2015, 5, 53172-53179. [CrossRef]

166. Kar, S.; Maiti, T.K.; Chakraborty, S. Capillarity-driven blood plasma separation on paper-based devices. Analyst 2015, 140, 6473-6476. [CrossRef] [PubMed]

167. Yamada, K.; Takaki, S.; Komuro, N.; Suzuki, K.; Citterio, D. An antibody-free microfluidic paper-based analytical device for the determination of tear fluid lactoferrin by fluorescence sensitization of $\mathrm{Tb} 3+$. Analyst 2014, 139, 1637-1643. [CrossRef] [PubMed]

168. Mentele, M.M.; Cunningham, J.; Koehler, K.; Volckens, J.; Henry, C.S. Microfluidic paper-based analytical device for particulate metals. Anal. Chem. 2012, 84, 4474-4480. [CrossRef] [PubMed]

169. Neumaier, M.; Braun, A.; Wagener, C. Fundamentals of quality assessment of molecular amplification methods in clinical diagnostics. Clin. Chem. 1998, 44, 12-26. [PubMed]

170. Improvement RfCL, for AoCWA, Manufacturers of In Vitro Diagnostic Devices. Available online: https:/ / www.fda.gov/medicaldevices/deviceregulationandguidance/guidancedocuments/ucm079632.htm (accessed on 15 May 2017).

171. Hunsinger, P.; Zwarun, A. Manufacturing Method for an Occult Fecal Blood Test Slide. U.S. Patent US4,983,416 A, 8 January 1991. 
172. Yu, Y.S. Test Strips Having Reaction Zones and Channels Defined by a Thermally Transferred Hydrophobic Barrier. U.S. Patent US6,723,500 B2, 20 April 2004.

173. Fonner, D.E. Diagnostic Composition. U.S. Patent US3001915 A, 26 September 1961.

174. Deiss, F.; Mazzeo, A.; Hong, E.; Ingber, D.E.; Derda, R.; Whitesides, G.M. Platform for high-throughput testing of the effect of soluble compounds on 3D cell cultures. Anal. Chem. 2013, 85, 8085-8094. [CrossRef] [PubMed]

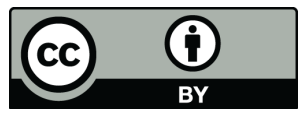

(C) 2017 by the authors. Licensee MDPI, Basel, Switzerland. This article is an open access article distributed under the terms and conditions of the Creative Commons Attribution (CC BY) license (http:/ / creativecommons.org/licenses/by/4.0/). 